\title{
Using Soil-Applied Fungicides to Manage Phytophthora Crown and Root Rot on Summer Squash
}

\author{
M. D. Meyer and M. K. Hausbeck, Department of Plant Pathology, Michigan State University, East Lansing 48824
}

\begin{abstract}
Meyer, M. D., and Hausbeck, M. K. 2013. Using soil-applied fungicides to manage Phytophthora crown and root rot on summer squash. Plant Dis. 97:107-112.

Phytophthora crown and root rot (Phytophthora capsici) of summer squash is especially difficult to manage because all commercial cultivars are highly susceptible to $P$. capsici. Producers have traditionally relied on foliar fungicide applications to control Phytophthora crown and root rot despite their limited efficacy. Soil fungicide applications, including via subsurface drip chemigation, have recently gained interest as a method of improving control of $P$. capsici infections. In this study, soil drenches and foliar applications of 11 fungicides were compared for control of Phytophthora crown and root rot of summer squash in replicated field and greenhouse trials. Fungicides were applied at 7-day intervals. Incidence (\%) of plant death was assessed from 7 to 42 days post inoculation (dpi) in field trials. Crown rot severity was rated on a scale of 1 (no wilting) to 5 (plant death) from 5 to 21 dpi in greenhouse trials. Results of field and greenhouse trials were similar. Plant death of 'Cougar' following inoculation with $P$. capsici isolate 12889 occurred at all growth stages from first true-leaf to full maturity in field trials. Plant death 42 dpi differed significantly $(P \leq$ $0.0001)$ among fungicides and application methods. The fungicideapplication method interaction also was significant. Some fungicides

were ineffective regardless of application method. In general, soil drenches were more effective than foliar applications at limiting plant death but no treatment completely controlled disease symptoms. Mean plant death 42 dpi was $41 \%$ for soil drenches and $92 \%$ for foliar sprays. Drenches of fluopicolide, mandipropamid, or dimethomorph limited plant death to $\leq 10 \%$ and prevented yield loss associated with root and crown rot. Foliar applications generally did not reduce plant death compared with the untreated, inoculated control, and were unable to prevent yield loss in field trials. In greenhouse trials, crown rot severity differed significantly $(P \leq 0.0001)$ among fungicides, application methods, and cultivars when plants were inoculated with $P$. capsici isolate 12889 or SP98. Crown rot was less severe and disease progress was slower following soil drenches than foliar applications. Some fungicide treatments were more effective on 'Leopard,' which was less susceptible to $P$. capsici than 'Cougar.' Soil application methods, including soil drench and drip chemigation, should be evaluated when fungicides are registered for soilborne disease control, because these methods provide better control of Phytophthora crown and root rot than foliar application.
\end{abstract}

Michigan is the largest producer of squash (Cucurbita spp.) for processing and fresh market consumption in the United States, accounting for $20 \%$ of total production (3). Phytophthora capsici Leonian (23) is an economically important soilborne pathogen of summer squash (Cucurbita pepo L.) and other vegetable crops (14). Yield losses due to Phytophthora blight can be substantial in soils heavily infested with $P$. capsici. In Michigan, complete crop failure has been reported in numerous vegetable crops, including summer squash, resulting in considerable financial losses for producers (14). All plant tissues, including roots, crowns, fruit, and leaves, are susceptible to $P$. capsici (4). Phytophthora crown and root rot is particularly severe, resulting in permanent wilting and rapid plant death $(13,14,37)$.

Successful management of Phytophthora crown and root rot requires an integrated approach $(14,15,36)$. Crop rotation and destruction of infected plant debris are not effective as stand-alone management practices because $P$. capsici is capable of surviving in the absence of a host for extended periods of time (22). Cultural practices, including planting on raised beds, using plastic mulches (42), and irrigation management $(6,7,44)$, limit disease but do not provide complete control. Resistance to Phytophthora crown rot has been identified in germplasm accessions of $C$. pepo (30) and $C$. moschata Duchesne (8) but has not been incorporated into

Corresponding author: M. K. Hausbeck, E-mail: hausbec1@msu.edu

* The $e$-Xtra logo stands for "electronic extra" and indicates that a supplementary figure appears in the online edition.

Accepted for publication 12 August 2012.

http://dx.doi.org/10.1094/PDIS-12-11-1071-RE

(C) 2013 The American Phytopathological Society commercial breeding lines. Presently, all commercial summer squash cultivars are highly susceptible to $P$. capsici. Hence, growers have relied on foliar fungicide applications in conjunction with cultural practices to manage Phytophthora crown and root rot despite their limited efficacy.

Metalaxyl and mefenoxam (metalaxyl-M) have been widely used to manage Phytophthora root, crown, and fruit rot on vegetable crops since the early 1980 s $(5,19,39,41)$. Repeated use of metalaxyl and mefenoxam has resulted in the selection of resistant isolates of $P$. capsici $(9,21,28,31-33)$. Resistance to metalaxylbased products necessitates additional fungicides and novel methods of fungicide application to improve control of $P$. capsici.

Soil fungicide application, including subsurface drip chemigation, has recently gained attention as a method of improving control of Phytophthora crown and root rot. Pepper (Capsicum annuum L.) plant survival in $P$. capsici-infested soil was greatest when dimethomorph was applied as a soil drench in an evaluation of five fungicides (26). Similarly, soil applications of acibenzolar$S$-methyl increased plant survival and restricted the development of stem lesions caused by $P$. capsici (27). Plant death due to Phytophthora crown and root rot was 2.5 times greater when fungicides were applied as foliar sprays compared with when the same products were applied as soil drenches in a greenhouse evaluation of nine fungicides on two pepper cultivars (11). Phosphonates applied as a soil drench reduced the severity of Phytophthora crown rot on pumpkin and zucchini seedlings, whereas foliar applications did not (45). Fluopicolide applied through drip irrigation at transplanting and as a foliar spray at weekly intervals reduced plant death in yellow summer squash (16).

Although some studies, primarily on pepper, have evaluated soil applications of fungicides for managing Phytophthora crown and root rot, additional research is needed to develop effective methods for fungicide use on summer squash in Michigan's production fields. The objective of this study was to evaluate the effects of 11 
fungicides and two application methods (foliar spray and soil drench) for managing Phytophthora crown and root rot, and to compare the effects of fungicide treatments on two summer squash cultivars differing in susceptibility to $P$. capsici.

\section{Materials and Methods}

Inoculum preparation. Two Michigan isolates of $P$. capsici originally collected from pumpkin (SP98) and pepper (12889) and maintained in the culture collection of M. K. Hausbeck at Michigan State University were used as inocula in this study. Isolates SP98 and 12889 are highly virulent and have been used in previous studies screening for $P$. capsici resistance $(10,12,35)$. Mating type and sensitivity to mefenoxam differed among the isolates. Isolate SP98 (mating type A2) is sensitive to mefenoxam at $100 \mathrm{ppm}$. Isolate 12889 (mating type A1) is insensitive to mefenoxam. Cultures were grown on unclarified V8 juice agar (UCV8) at room temperature $\left(21 \pm 2^{\circ} \mathrm{C}\right)$ under constant fluorescent light. $P$. capsiciinfested millet seed was produced for each isolate as described by Quesada-Ocampo et al. (34).

Field evaluation. Two separate trials were conducted at the Michigan State University Southwest Michigan Research and Extension Center in Benton Harbor. Plots were previously planted to a cover crop of cereal rye (Secale cereale L.) and hairy vetch (Vicia villosa Roth). The soil type was Spinks loamy fine sand (sandy, mixed, mesic Lamellic Hapludalfs). Susceptible yellow straightneck squash 'Cougar' (Harris Moran Seed Co.) was grown in both trials. Planting dates were 25 May 2010 (trial 1) and 29 July 2010 (trial 2). Seeds were planted in raised beds $(15 \mathrm{~cm}$ high by $60 \mathrm{~cm}$ wide) covered with black, plastic mulch. Beds were spaced $1.7 \mathrm{~m}$ apart. Plants were spaced $46 \mathrm{~cm}$ apart within beds. Plants were irrigated twice weekly for 3 to $4 \mathrm{~h}$ using drip irrigation. The experimental design was a randomized complete block with four replicates. An experimental unit was one 6.9-m-long bed with 15 plants.

Plants were inoculated with $P$. capsici isolate 12889 at the first true-leaf stage. A 3-cm-deep hole was made approximately $2 \mathrm{~cm}$ from the crown of each plant. $P$. capsici-infested millet seed $(1 \mathrm{~g})$ was placed in each hole and covered with soil. Fungicides were applied immediately after inoculation and at 7-day intervals thereafter until 42 days post inoculation (dpi). Fungicides and application rates are listed in Table 1. Control plots were not treated with fungicides. Foliar applications were applied using a $\mathrm{CO}_{2}$-pressurized backpack sprayer and hand-held boom equipped with three TeeJet XR8003 flat-fan nozzles spaced $46 \mathrm{~cm}$ apart. One nozzle was positioned directly above the canopy and two lateral nozzles were positioned downward at a $45^{\circ}$ angle toward the plant crown. All foliar sprays were applied in a volume of 468 liter/ha at 345 $\mathrm{kPa}$. Soil drenches were applied using a $\mathrm{CO}_{2}$-pressurized backpack sprayer and spray wand equipped with one TeeJet XR8010 nozzle calibrated to deliver $80 \mathrm{ml} / \mathrm{plant}$ at $89 \mathrm{kPa}$. The soil drench treatment was applied at the soil line near the crown of each plant.
Disease incidence, defined as the percentage of wilted or dead plants in each plot, was measured at 7-day intervals from 7 to 42 dpi in field trials. Area under the disease progress curve (AUDPC) values for disease incidence were calculated according to the formula presented by Shaner and Finney (40). Squash fruit were hand harvested from healthy plants in each plot and weighed. Plants were harvested every 3 or 4 days over a 3 -week period. Relative yield of fungicide-treated plots was calculated as a proportion of the yield obtained in uninoculated control plots within replicates, where relative yield $=$ (yield of fungicide treated plot/yield of uninoculated control plot).

Greenhouse evaluation. Greenhouse trials were done in May (trial 1) and September (trial 2) 2010 at the Michigan State University Horticulture Research and Teaching Center in Holt. Susceptible yellow straightneck squash Cougar and green zucchini 'Leopard' (Harris Moran Seed Co.) were grown in both experiments under natural light. The experimental design was completely randomized with six replicates. An experimental unit was one plant grown in a $10-\mathrm{cm}$-diameter pot containing soilless potting mix (BACCTO High Porosity Professional Potting Mix; Michigan Peat Co., Houston, TX). A single fungicide-application method combination was assigned randomly to each plant.

Plants were inoculated with $P$. capsici as described above for field trials. Isolates SP98 and 12889 were evaluated in separate, concurrent trials. Fungicides were applied immediately after inoculation and at 7-day intervals thereafter until $21 \mathrm{dpi}$. Fungicides and application rates were the same for greenhouse and field trials (Table 1). Volume and methods of application were as described above for field trials, with the exception that soil drenches were applied by hand using a plastic bottle. A drench volume of $80 \mathrm{ml}$ saturated the potting mix contained within a $10-\mathrm{cm}$-diameter pot without leaching from the bottom.

Disease severity was assessed at 2- or 3-day intervals from 5 to 21 dpi. Each plant was visually assessed using a 1-to-5 scale similar to that described by Yandoc-Ables et al. (45), where $1=$ no symptoms; 2 = lower leaves wilted, with slight constriction of the stem; 3 = all leaves wilted, with constriction and slight discoloration of the stem; 4 = all leaves wilted and crown rotted, with visible sporulation on the stem surface; and $5=$ plant dead (Supplementary Figure S1). AUDPC values were calculated using disease severity ratings.

Pathogen confirmation. Approximately 5\% of symptomatic plants from field and greenhouse trials were sampled for pathogen confirmation. Symptomatic plants were arbitrarily selected from treatment plots and sheared at the soil line with hand pruners. Crown sections were surface disinfested with a $70 \%$ ethanol solution and blotted dry with paper toweling. Four pieces of tissue were excised from each crown and plated on UCV8 amended with benomyl at $25 \mathrm{ppm}$, ampicillin at $100 \mathrm{ppm}$, rifampicin at $30 \mathrm{ppm}$, and pentachloronitrobenzene at $100 \mathrm{ppm}$. Colonies were identified as $P$. capsici using morphological characteristics and a key devel-

Table 1. Fungicides and rates of application evaluated for managing Phytophthora crown and root rot caused by Phytophthora capsici on summer squash in field and greenhouse trials

\begin{tabular}{|c|c|c|c|c|}
\hline Trade name & Active ingredient (a.i.) & Manufacturer $^{y}$ & FRAC $\operatorname{code}^{\mathrm{z}}$ & Rate (a.i./ha $[\mathrm{kg}])$ \\
\hline Forum 4.17SC & Dimethomorph & BASF & 40 & 0.22 \\
\hline Gavel 75DF & Mancozeb + zoxamide & Gowan & $\mathrm{M} 3 / 22$ & $1.50 / 0.19$ \\
\hline Kocide 3000 46.1DF & Copper hydroxide & DuPont & M1 & 0.65 \\
\hline Presidio 4SC & Fluopicolide & Valent & 43 & 0.14 \\
\hline Previcur Flex 6EC & Propamocarb hydrochloride & Bayer & 28 & 1.01 \\
\hline ProPhyt $4.2 \mathrm{~L}$ & Potassium phosphite & Helena & 33 & 3.53 \\
\hline Ranman 3.6SC & Cyazofamid & FMC & 21 & 0.08 \\
\hline Reason 5004.13 SC & Fenamidone & Bayer & 11 & 0.20 \\
\hline Revus 2.08SC & Mandipropamid & Syngenta & 40 & 0.15 \\
\hline Ridomil Gold SL 4EC & Mefenoxam & Syngenta & 4 & 1.12 \\
\hline Tanos 50WG & Famoxadone + cymoxanil & DuPont & $11 / 27$ & $0.18 / 0.18$ \\
\hline
\end{tabular}

y BASF = BASF Corp., Research Triangle Park, NC; Gowan = Gowan Co., Yuma, AZ; DuPont = E. I. du Pont de Nemours and Co., Wilmington, DE; Valent = Valent USA Corp., Walnut Creek, CA; Bayer = Bayer CropScience LP, Research Triangle Park, NC; Helena = Helena Chemical Co., Collierville, TN; FMC = FMC Corp., Agricultural Products Group, Philadelphia; Syngenta = Syngenta Crop Protection, Inc., Greensboro, NC .

${ }^{\mathrm{z}} \mathrm{FRAC}=$ Fungicide Resistance Action Committee. 
oped by Waterhouse (43). Mating type and sensitivity to mefenoxam were determined for each isolate and compared with the phenotype of isolates used as inoculum.

Statistical analysis. For field trials, final incidence of plant death, AUDPC, and relative yield were analyzed separately by analysis of variance (ANOVA) using the Proc Mixed procedure of SAS (version 9.2; SAS Institute). Trials and blocks were consid-

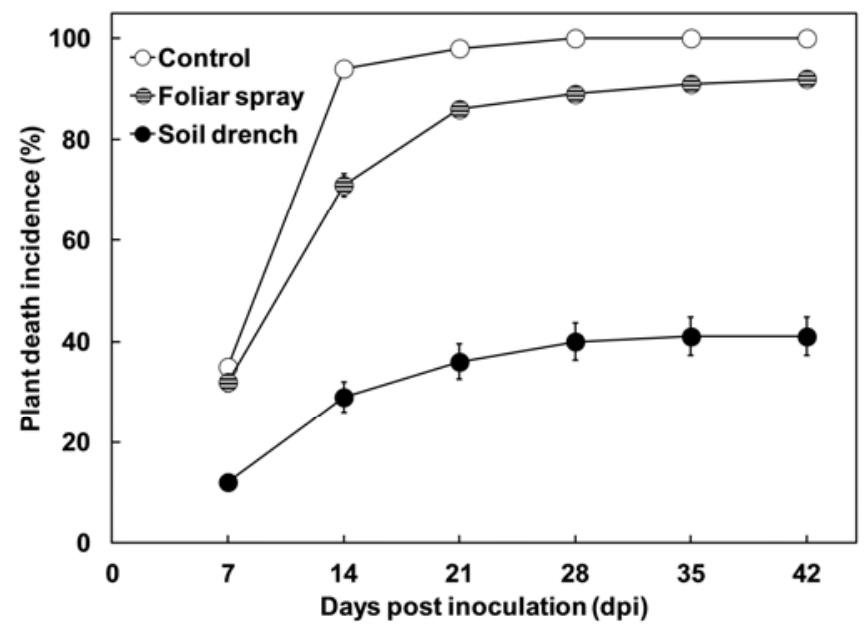

Fig. 1. Incidence (\%) of plant death in summer squash 'Cougar' grown in field plots treated with fungicides applied as a foliar spray or soil drench to control Phytophthora crown and root rot caused by Phytophthora capsici. Data points are the means of 11 fungicides and eight replicates. Error bars represent the standard error of the mean. ered random variables. Fungicides and application methods were considered fixed variables. Pearson correlation coefficients between relative yield and disease incidence were calculated using the Proc Corr procedure of SAS. For greenhouse trials, final crown rot severity and AUDPC were analyzed separately for each isolate by ANOVA using the Proc Mixed procedure of SAS. Trials were considered random variables. Fungicide treatments, application methods, and cultivars were considered fixed variables. Slice statements were used to test simple main effects, when two-way interactions were statistically significant. Fungicide treatment means were separated by Fisher's protected least significant difference using the pdmix800 SAS macro (38). Residuals were tested for normality using the Shapiro-Wilk statistic in the Proc Univariate procedure of SAS. Residuals were plotted against predicted values using the Proc Gplot procedure of SAS to assess homoscedasticity.

\section{Results}

Field evaluation. Plant death associated with Phytophthora crown and root rot occurred at all growth stages from expansion of the first true-leaf to full maturity. $P$. capsici with the same phenotype as 12889 was consistently isolated from symptomatic plants. Incidence of plant death increased rapidly from 7 to 21 dpi (Fig. 1). Plant death 42 dpi in inoculated control plots was $100 \%$ (Fig. 2). Little or no plant death occurred in uninoculated control plots. Results of analyses of plant death incidence and AUDPC were similar. A significant trial-treatment interaction was primarily accounted for by changes in magnitude among soil drenches rather than in rank; therefore, data were pooled for analysis. Plant death 42 dpi and AUDPC differed significantly $(P \leq 0.0001)$ among fungicides and application methods. The fungicide-application method interaction also was significant $(P \leq 0.0001)$. No treatment

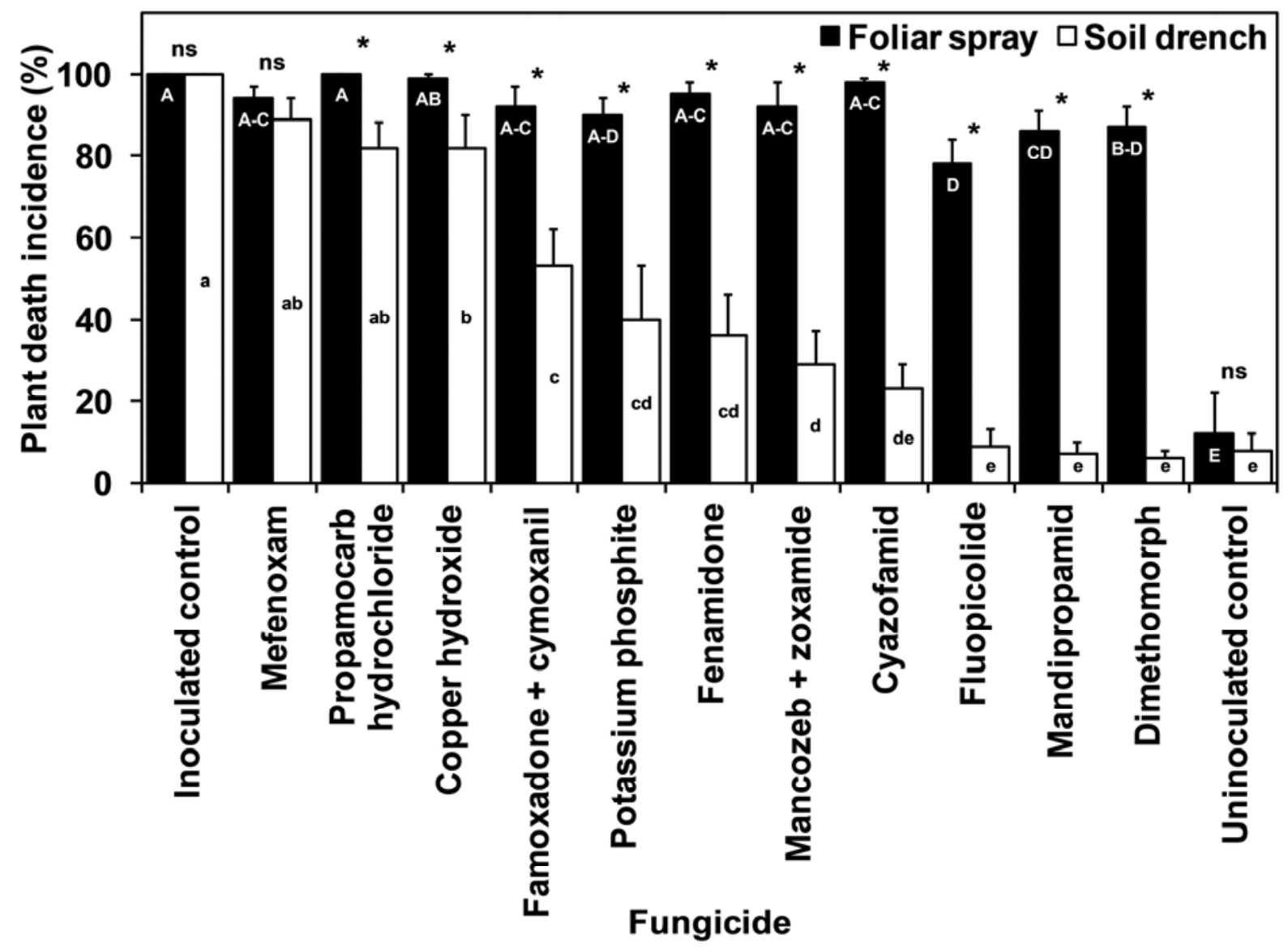

Fig. 2. Incidence (\%) of plant death 42 days post inoculation in summer squash 'Cougar' grown in field plots treated with fungicides applied as a foliar spray or soil drench to control Phytophthora crown and root rot caused by Phytophthora capsici. Values represent the mean of eight replicates. Error bars represent the standard error of the mean. Within an application method, bars with a common letter do not differ significantly based on Fisher's protected least significant difference test at $\alpha=0.05$. For each fungicide, an asterisk indicates that application methods differed significantly based on single degree-of-freedom slice statements used to partition the fungicide-method interaction at $\alpha=0.05$. 
combination (fungicide-application method) completely controlled disease symptoms. In general, treatment combinations that reduced plant death also limited AUDPC (Table 2; Fig. 2). Plant death and AUDPC were high regardless of application method for some fungicides with less activity against $P$. capsici. For example, mefenoxam was ineffective regardless of application method because $P$. capsici isolate 12889 is mefenoxam-resistant (Table 2; Fig. 2).

Soil drenches were generally more effective in limiting disease than foliar sprays. Among foliar sprays, plant death 42 dpi ranged from 53 to $100 \%$ and averaged $92 \%$ for the 11 fungicides. Foliar sprays of fluopicolide, mandipropamid, and dimethomorph reduced plant death compared with the inoculated control (Fig. 2). Mean plant death 42 dpi was $84 \%$ following foliar applications of these fungicides. Fluopicolide sprays also reduced AUDPC (Table 2). Plant death 42 dpi varied among soil drenches, ranging from 0 to $100 \%$ and averaging $41 \%$ for the 11 fungicides. Soil drenches of nine fungicides reduced plant death compared with the inoculated control (Fig. 2). These fungicides, with the exception of copper hydroxide, also reduced AUDPC (Table 2). Plant death 42 dpi was $<10 \%$ when dimethomorph, mandipropamid, or fluopicolide was applied as a soil drench (Fig. 2).

Relative yield of inoculated control plots was zero because all plants died following inoculation with $P$. capsici. Relative yield differed significantly $(P \leq 0.0001)$ among fungicides and application methods. The fungicide-application method interaction also was significant $(P \leq 0.0001)$. Some fungicides were unable to prevent yield losses regardless of application method. Mean relative yield was 17 and $72 \%$ for foliar sprays and soil drenches, respectively (Table 2). No fungicides prevented yield losses when applied as a foliar spray (Table 2). Soil drenches of cyazofamid, fluopicolide, mancozeb + zoxamide, mandipropamid, dimethomorph, or fenamidone prevented significant yield losses (Table 2). Plant death was $\leq 36 \%$ in plots treated with these fungicide drenches and yield loss was zero.

Greenhouse evaluation. Disease symptoms began to develop 5 dpi. Most inoculated control plants died by 21 dpi, whereas uninoculated control plants remained asymptomatic. The phenotype of $P$. capsici isolated from symptomatic plants matched that of the isolate used for inoculum. In general, crown rot was more severe following inoculation with $P$. capsici isolate 12889 than SP98. Results from analyses of crown rot severity and AUDPC were similar. Crown rot severity differed significantly $(P \leq 0.0001)$ among application methods, fungicides, and cultivars in the ANOVAs for both isolates (Table 3; Fig. 3A and B). The fungicide-application method and the fungicide-cultivar interactions also were significant $(P \leq 0.0001)$ for both isolates. Crown rot on both cultivars was less severe for soil drenches compared with foliar sprays for nine fungicides in both trials (Table 3). Crown rot was not affected by application method for copper hydroxide or mefenoxam, regardless of cultivar (Table 3). In general, treatment combinations (fungicide-application method) were more effective on 'Leopard,' which is less susceptible than 'Cougar' (Table 3; Fig. $3 \mathrm{~A}$ and B). For isolate SP98 only, the application method-cultivar and the fungicide-application method-cultivar interactions were significant $(P \leq 0.05)$. When the untreated controls, copper hydroxide, and mefenoxam were excluded from the analysis, these interactions were not significant.

\section{Discussion}

Applying fungicides to the soil represents a significant change in management strategy because growers have traditionally managed Phytophthora crown and root rot using foliar fungicide applications. In this study, fungicides with activity against $P$. capsici were most effective at controlling Phytophthora crown and root rot on summer squash when applied as a soil drench. Foliar applications did not adequately reduce AUDPC or the final incidence of plant death and were unable to prevent yield losses. These results are in agreement with previous research. In a greenhouse study, Foster and Hausbeck (11) demonstrated that soil drenches were more effective than foliar applications at reducing AUDPC and pepper plant death caused by $P$. capsici. In a separate study, phosphonate drenches reduced the severity of crown rot on zucchini and pumpkin seedlings, whereas foliar applications did not (45). Fungicide drenches are likely more effective than foliar applications due to increased contact with the plant root system and $P$. capsici propagules in the soil. Furthermore, the dense canopy of summer squash leaves may prevent adequate coverage of lower portions of the plant when fungicides are applied as a foliar spray.

Among the fungicides evaluated in this study, fluopicolide, mandipropamid, and dimethomorph consistently reduced disease progress and symptoms associated with Phytophthora crown and root rot in both field and greenhouse trials. In the greenhouse, levels of control were similar for both $P$. capsici isolates used as inoculum. Recently, fluopicolide was registered for application through drip irrigation systems (i.e., subsurface drip chemigation) to control

Table 2. Area under the disease progress curve (AUDPC) values for plant death and relative yield of summer squash 'Cougar' grown in field trials evaluating fungicides applied as a foliar spray or soil drench to control Phytophthora crown and root rot caused by Phytophthora capsici

\begin{tabular}{|c|c|c|c|c|}
\hline \multirow[b]{2}{*}{ Fungicide treatment ${ }^{y}$} & \multicolumn{2}{|c|}{ AUDPC $^{w}$} & \multicolumn{2}{|c|}{ Relative yield $(\%)^{x}$} \\
\hline & Foliar spray & Soil drench & Foliar spray & Soil drench \\
\hline Inoculated control & $2,812 \mathrm{a}-\mathrm{c}$ & 2,841 a & $0 *$ & $0^{*}$ \\
\hline Mefenoxam & $2,892 \mathrm{a}-\mathrm{c}$ & $2,576 a b$ & 9* & $9 *$ \\
\hline Copper hydroxide & $3,094 \mathrm{ab}$ & $2,559 \mathrm{ab}$ & $3 *$ & $32 *$ \\
\hline Propamocarb hydrochloride & $2,874 \mathrm{a}-\mathrm{c}$ & $2,041 \mathrm{bc}$ & $2^{*}$ & $21^{*}$ \\
\hline Famoxadone + cymoxanil & $2,674 \mathrm{~cd}$ & $1,672 \mathrm{~cd}$ & $9 *$ & $59^{*}$ \\
\hline Fenamidone & $2,947 \mathrm{a}-\mathrm{c}$ & $1,105 \mathrm{de}$ & $12 *$ & 88 \\
\hline Potassium phosphite & $2,675 \mathrm{~cd}$ & $1,094 \mathrm{e}$ & $23^{*}$ & $67 *$ \\
\hline Mancozeb + zoxamide & $2,772 \mathrm{a}-\mathrm{c}$ & 897 e & $13 *$ & 104 \\
\hline Cyazofamid & $3,130 \mathrm{a}$ & 730 ef & $7 *$ & 109 \\
\hline Fluopicolide & $2,375 \mathrm{~d}$ & $210 \mathrm{fg}$ & $46^{*}$ & 108 \\
\hline Mandipropamid & $2,580 \mathrm{~cd}$ & $173 \mathrm{fg}$ & $30^{*}$ & 101 \\
\hline Dimethomorph & $2,727 b-d$ & $146 \mathrm{~g}$ & $29 *$ & 94 \\
\hline Uninoculated control & 187 e & $130 \mathrm{~g}$ & 100 & 100 \\
\hline Mean & 2,795 & 1,200 & $17^{\mathrm{z}}$ & 72 \\
\hline FLSD $(\alpha=0.05)$ & 393 & 575 & 18 & 24 \\
\hline
\end{tabular}

${ }^{\text {w}}$ AUDPC was calculated for plant death incidence assessed at 7-day intervals from 7 to 42 days post inoculation (dpi). Within columns, AUDPCs with a common letter do not differ significantly based on Fisher's protected least significant difference (FLSD) at $\alpha=0.05$.

${ }^{x}$ Relative yield was calculated as the percentage of yield in uninoculated control plots. Within an application method, values followed by an asterisk differed significantly from the uninoculated control based on FLSD at $\alpha=0.05$.

${ }^{y}$ Fungicides were applied as a foliar spray or soil drench following inoculation with Phytophthora capsici and at 7-day intervals thereafter until 42 days post inoculation.

${ }^{\mathrm{z}}$ Uninoculated control plots were excluded from the calculation of mean relative yield for application methods. 
"soilborne infections" on cucurbits and other vegetable crops (2). Field trials in Georgia have demonstrated the efficacy of fluopicolide application through drip irrigation systems for controlling $P$. capsici on yellow summer squash (16). Results from this study confirm that soil applications of fluopicolide are highly effective at preventing plant death associated with Phytophthora crown and root rot. Resistance to fluopicolide, mandipropamid, or dimethomorph has not been reported in P. capsici populations from Michigan. However, P. capsici isolates from Michigan were less sensitive to fluopicolide compared with isolates from four southeastern states (20). Lu et al. (24) were able to generate fluopicolide-resistant mutants of $P$. capsici in the laboratory, and determined the risk of $P$. capsici developing resistance to fluopicolide in the field to be moderately high. To delay the development of resistance, fluopicolide should be used in rotation with fungicides with different modes of action such as mandipropamid or dimethomorph. Cross-resistance to multiple carboxylic acid amide (CAA) fungicides, including dimethomorph and mandipropamid, has been reported in some $P$. capsici populations $(17,25)$. Therefore, these fungicides should not be used exclusively or in tank mixtures.

Subsurface drip chemigation of fungicides to manage soilborne diseases, including Phytophthora crown and root rot, is expected to increase as vegetable producers discontinue the practice of soil fumigation with methyl bromide. In addition to accurately delivering fungicide to the plant root system, drip chemigation may reduce applicator exposure, application costs, and fossil fuel use compared with application with ground rig sprayers $(1,18)$. Also, drip chemigation can be performed during poor field conditions that prohibit application by ground rig $(1,18)$. Among the fungicides evaluated in this study, only fluopicolide (Presidio 4SC) and mefenoxam (Ridomil Gold 4SL) are registered for drip chemigation. Numerous factors affect the efficacy of soil applications, including fungicide concentration, formulation, and placement, as well as soil characteristics, including texture, moisture, and organic matter content (29). Additional studies are necessary to determine whether fungicides that suppressed Phytophthora crown and root rot as a soil drench in this study are also effective when applied by drip chemigation. Furthermore, the optimal interval between soil fungicide applications needs to be determined. Fungicides were applied at 7-day intervals in this study; however, soil applications may need to be applied less frequently than foliar applications.
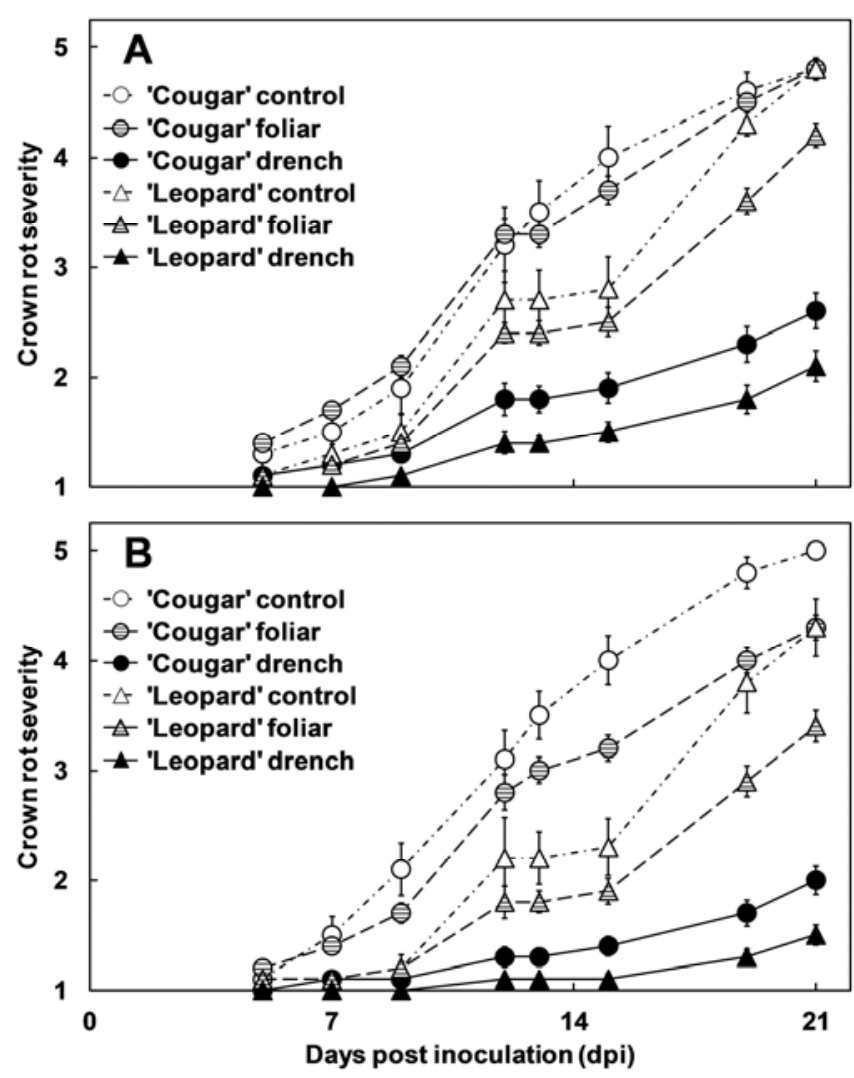

Fig. 3. Development of crown rot on summer squash 'Cougar' and 'Leopard' inoculated with Phytophthora capsici A, isolate 12889 or B, isolate SP98 in greenhouse trials evaluating the efficacy of foliar spray (foliar) and soil drench (drench) applications of 11 fungicides. Crown rot severity was rated from 5 to 21 days post inoculation on a 1 -to- 5 scale, where $1=$ no symptoms; $2=$ lower leaves wilted, with slight constriction of the stem; $3=$ all leaves wilted, with constriction and slight discoloration of the stem; $4=$ all leaves wilted and crown rotted with visible sporulation on the stem surface; and $5=$ plant dead. Ratings are the means of 11 fungicides and 12 replicates. Error bars represent the standard error of the mean.

Table 3. Mean crown rot severity on summer squash 'Cougar' and 'Leopard' following inoculation with Phytophthora capsici isolate 12889 or SP98 in greenhouse trials evaluating foliar spray (Spray) and soil drench (Drench) applications of 11 fungicides for controlling Phytophthora crown and root rot

\begin{tabular}{|c|c|c|c|c|c|c|c|c|}
\hline \multirow[b]{4}{*}{ Fungicide treatment $^{\mathrm{z}}$} & \multicolumn{8}{|c|}{ Crown rot severity 21 days post inoculation (dpi) ${ }^{y}$} \\
\hline & \multicolumn{4}{|c|}{ P. capsici isolate 12889} & \multicolumn{4}{|c|}{ P. capsici isolate SP98 } \\
\hline & \multicolumn{2}{|c|}{ Cougar } & \multicolumn{2}{|c|}{ Leopard } & \multicolumn{2}{|c|}{ Cougar } & \multicolumn{2}{|c|}{ Leopard } \\
\hline & Spray & Drench & Spray & Drench & Spray & Drench & Spray & Drench \\
\hline Inoculated control & 5.0 & $4.7 \mathrm{~ns}$ & 4.8 & $4.9 \mathrm{~ns}$ & 4.9 & $5.0 \mathrm{~ns}$ & 4.2 & $4.3 \mathrm{~ns}$ \\
\hline Copper hydroxide & 5.0 & $4.7 \mathrm{~ns}$ & 4.8 & $4.5 \mathrm{~ns}$ & 4.7 & $5.0 \mathrm{~ns}$ & 3.8 & $3.5 \mathrm{~ns}$ \\
\hline Mefenoxam & 5.0 & $4.3 \mathrm{~ns}$ & 3.5 & $2.4 \mathrm{~ns}$ & 1.7 & $1.2 \mathrm{~ns}$ & 1.0 & $1.0 \mathrm{~ns}$ \\
\hline Dimethomorph & 5.0 & $3.8 *$ & 4.6 & $2.5 *$ & 4.8 & $1.7 *$ & 3.9 & $1.7 *$ \\
\hline Fenamidone & 4.8 & $3.3 *$ & 4.4 & $2.2 *$ & 4.7 & $1.8 *$ & 4.1 & $1.4 *$ \\
\hline Cyazofamid & 4.8 & $3.2 *$ & 4.5 & $3.3 *$ & 4.8 & $3.9 *$ & 4.0 & $1.3 *$ \\
\hline Mancozeb + zoxamide & 4.8 & $2.8 *$ & 4.3 & $2.3 *$ & 4.6 & $2.2 *$ & 4.0 & $1.8 *$ \\
\hline Mandipropamid & 4.9 & $2.3 *$ & 5.0 & $1.6 *$ & 4.8 & $1.3 *$ & 3.9 & $1.3 *$ \\
\hline Potassium phosphite & 4.9 & $1.4 *$ & 3.7 & $1.3 *$ & 4.8 & $1.3 *$ & 3.8 & $1.2 *$ \\
\hline Fluopicolide & 4.9 & $1.1 *$ & 4.5 & $1.0 *$ & 4.4 & $1.0 *$ & 3.8 & $1.0 *$ \\
\hline Propamocarb hydrochloride & 3.6 & $1.0 *$ & 3.1 & $1.0 *$ & 3.9 & $1.3 *$ & 2.1 & $1.0 *$ \\
\hline Famoxadone + cymoxanil & 4.7 & $1.0 *$ & 3.2 & $1.0 *$ & 4.5 & $1.0 *$ & 3.2 & $1.0 *$ \\
\hline Uninoculated control & 1.0 & $1.0 \mathrm{~ns}$ & 1.0 & $1.0 \mathrm{~ns}$ & 1.0 & $1.0 \mathrm{~ns}$ & 1.0 & $1.0 \mathrm{~ns}$ \\
\hline Mean & 4.8 & 2.6 & 4.2 & 2.1 & 4.3 & 2.0 & 3.4 & 1.5 \\
\hline FLSD $(\alpha=0.05)$ & 0.4 & 0.9 & 0.9 & 1.0 & 0.7 & 0.6 & 1.0 & 0.7 \\
\hline
\end{tabular}

${ }^{\mathrm{y}}$ Crown rot severity was rated from 5 to $21 \mathrm{dpi}$ on a 1 -to- 5 scale, where $1=$ no symptoms; $2=$ lower leaves wilted, with slight constriction of the stem; $3=$ all leaves wilted, with constriction and slight discoloration of the stem; $4=$ all leaves wilted and crown rotted with visible sporulation on the stem surface; and 5 = plant dead. Plants grown in separate, concurrent trials were inoculated with P. capsici isolate 12889 or isolate SP98. For a given isolate-cultivarfungicide combination, an asterisk indicates that application methods differed significantly based on single degree-of-freedom slice statements used to partition the fungicide-method interaction at $\alpha=0.05 ; \mathrm{ns}=$ not significant. Values represent the mean of 12 replicates.

${ }^{\mathrm{z}}$ Fungicides were applied as a foliar spray or soil drench following inoculation with P. capsici and at 7-day intervals thereafter until 21 dpi. Untreated control plots were excluded from calculation of the mean. FLSD = Fisher's protected least significant difference. 
Currently, few fungicides are registered for application by soil drench or drip chemigation. Therefore, foliar fungicide sprays will continue to be necessary, especially for managing Phytophthora fruit rot and foliar blight, which did not occur in this study. Crowndirected applications may penetrate the canopy better than broadcast applications, resulting in improved coverage of the lower portions of the plant. Some of the fungicides evaluated may be more or less effective at controlling foliar blight and fruit rot than root and crown rot. For example, copper hydroxide has been recommended in fungicide tank mixes for Phytophthora fruit rot control (14); however, results from this study indicate that it does not control root and crown rot.

Fungicides are most effective when used in combination with host resistance and cultural practices $(11,14,15)$. 'Cougar' and 'Leopard' differed in susceptibility to $P$. capsici in this study; however, plant death and severe crown rot occurred on both cultivars by $21 \mathrm{dpi}$. These cultivars likely do not possess levels of field resistance that are of commercial significance for Phytophthora crown and root rot management. Research to identify sources of $P$. capsici resistance in cucurbit germplasm has been limited $(8,12,30)$. Additional studies are necessary to screen for $P$. capsici resistance genes and incorporate them into commercially available cultivars. In the meantime, growers should integrate fungicide use with cultural practices, including the use of domeshaped raised beds, plastic mulches, and drip irrigation, to manage Phytophthora crown and root rot in production fields.

\section{Acknowledgments}

This research is based upon work supported by the United States Department of Agriculture NIFA Special Research Grant Award Numbers 2010-3438121286 and 2009-34572-19990, Michigan State University SWMREC Award Number FY 10-02, and the Pickle and Pepper Research Committee of Michigan State University, Pickle Packers International, Inc. We thank B. Cortright, A. Cortright, A. Cook, and B. Harlan for technical assistance; and L. Granke for her critical review of this manuscript.

\section{Literature Cited}

1. Anonymous. 2008. Drip Chemigation: Best Management Practices. Technical Bulletin. E.I. du Pont de Nemours and Co., Wilmington, DE.

2. Anonymous. 2010. Supplemental Label, 2010-PRD-0010.XCAHINY Presidio Drip Irrigation-Except CA, HI \& NY. Published online. Valent USA Corp, Walnut Creek, CA.

3. Anonymous. 2011. Vegetables 2010 Summary. Published online. U.S. Dep. Agric. Nat. Agric. Stat. Serv.

4. Babadoost, M. 2005. Phytophthora blight of cucurbits. The Plant Health Instructor. doi:10.1094/PHI-I-2005-0429-01

5. Babadoost, M., and Islam, S. Z. 2003. Fungicide seed treatment effects on seedling damping-off of pumpkin caused by Phytophthora capsici. Plant Dis. 87:63-68.

6. Café-Filho, A. C., and Duniway, J. M. 1996. Effect of location of drip irrigation emitters and position of Phytophthora capsici infections in roots on Phytophthora root rot of pepper. Phytopathology 86:1364-1369.

7. Café-Filho, A. C., Duniway, J. M., and Davis, R. M. 1995. Effects of the frequency of furrow irrigation on root and fruit rots of squash caused by Phytophthora capsici. Plant Dis.79:44-48.

8. Chavez, D. J., Kabelka, E. A., and Chaparro, J. X. 2011. Screening of Cucurbita moschata Duchesne germplasm for crown rot resistance to Floridian isolates of Phytophthora capsici Leonian. HortScience 46:536-540.

9. Dunn, A. R., Milgroom, M. G., Meitz, J. C., McLeod, A., Fry, W. E., McGrath, M. T., Dillard, H. R., and Smart, C. D. 2010. Population structure and resistance to mefenoxam of Phytophthora capsici in New York State. Plant Dis. 94:1461-1468.

10. Foster, J. M., and Hausbeck, M. K. 2010. Resistance of pepper to Phytophthora crown, root, and fruit rot is affected by isolate virulence. Plant Dis. 94:24-30.

11. Foster, J. M., and Hausbeck, M. K. 2010. Managing Phytophthora crown and root rot in bell pepper using fungicides and host resistance. Plant Dis. 94:697-702.

12. Gevens, A. J., Ando, K., Lamour, K. H., Grumet, R., and Hausbeck, M. K. 2006. A detached cucumber fruit method to screen for resistance to Phytophthora capsici and effect of fruit age on susceptibility to infection. Plant Dis. 90:1276-1282.

13. Gubler, W. D., and Davis, R. M. 1996. Phytophthora crown and root rot. Pages 19-20 in: Compendium of Cucurbit Diseases. T. A. Zitter, D. L. Hopkins, and C. E. Thomas, eds. American Phytopathological Society, St. Paul, MN.

14. Hausbeck, M. K., and Lamour, K. H. 2004. Phytophthora capsici on vegetable crops: research progress and management challenges. Plant Dis. $88: 1292-1303$
15. Hwang, B. K., and Kim, C. H. 1995. Phytophthora blight of pepper and its control in Korea. Plant Dis. 79:221-227.

16. Jackson, K. L., Yin, J., Csinos, A. S., and Ji, P. 2010. Fungicidal activity of fluopicolide for suppression of Phytophthora capsici on squash. Crop Prot. 29:1421-1427.

17. Jang, H. S., Lee, S. M., Kim, S. B., Kim, J., Knight, S., Park, K. D., McKenzie, D., and Kim, H. T. 2009. Baseline sensitivity to mandipropamid among isolates of Phytophthora capsici causing Phytophthora blight on pepper. J. Plant Pathol. 25:317-321.

18. Johnson, A. W., Young, J. R., Threadgill, E. D., Dowler, C. C., and Sumner, D. R. 1986. Chemigation for crop production management. Plant Dis. 70:998-1004.

19. Johnston, S. A. 1982. Control of the crown rot phase of Phytophthora blight of bell pepper with fungicides. Fungic. Nematicide Tests 37:73.

20. Keinath, A. P., and Kousik, C. S. 2011. Sensitivity of isolates of Phytophthora capsici from the eastern United States to fluopicolide. Plant Dis. 95:1414-1419.

21. Lamour, K. H., and Hausbeck, M. K. 2000. Mefenoxam insensitivity and the sexual stage of Phytophthora capsici in Michigan cucurbit fields. Phytopathology 90:396-400.

22. Lamour, K. H., and Hausbeck, M. K. 2003. Effect of crop rotation on the survival of Phytophthora capsici in Michigan. Plant Dis. 87:841-845.

23. Leonian, L. H. 1922. Stem and fruit blight of peppers caused by Phytophthora capsici sp. nov. Phytopathology 12:401-408.

24. Lu, X. H., Hausbeck, M. K., Liu, X. L., and Hao, J. J. 2011. Wild type sensitivity and mutation analysis for resistance risk to fluopicolide in Phytophthora capsici. Plant Dis. 95:1535-1541.

25. Lu, X. H., Zhu, S. S., Bi, Y., Liu, X. L., and Hao, J. J. 2010. Baseline sensitivity and resistance-risk assessment of Phytophthora capsici to iprovalicarb. Phytopathology 100:1162-1168.

26. Matheron, M. E., and Porchas, M. 2000. Comparison of five fungicides on development of root, crown, and fruit rot of chili pepper and recovery of Phytophthora capsici from soil. Plant Dis. 84:1038-1043.

27. Matheron, M. E., and Porchas, M. 2002. Suppression of Phytophthora root and crown rot on pepper plants treated with acibenzolar- $S$-methyl. Plant Dis. 86:292-297.

28. Mathis, W. L., Williams-Woodward, J., and Csinos, A. S. 1999. Insensitivity of Phytophthora capsici to mefenoxam in Georgia. (Abstr.) Phytopathology 89:S49.

29. Munnecke, D. E. 1972. Factors affecting the efficacy of fungicides in the soil. Annu. Rev. Phytopathol. 10:375-398.

30. Padley, L. D., Jr., Roberts, P. D., French, R., and Kabelka, E. A. 2008. Evaluation of Cucurbita pepo accessions for crown rot resistance to isolates of Phytophthora capsici. HortScience 43:1996-1999.

31. Parra, G., and Ristaino, J. 1998. Insensitivity to Ridomil Gold (mefenoxam) found among field isolates of Phytophthora capsici causing Phytophthora blight on bell pepper in North Carolina and New Jersey. Plant Dis. 82:711.

32. Parra, G., and Ristaino, J. B. 2001. Resistance to mefenoxam and metalaxy among field isolates of Phytophthora capsici causing Phytophthora blight of bell pepper. Plant Dis. 85:1069-1075.

33. Ploetz, R. C., Haynes, J., Heine, G., and Watson, M. 2001. Investigating factors that may contribute to the increased prevalence of Phytophthora capsci-induced diseases in South Florida. (Abstr.) Phytopathology 91:S72.

34. Quesada-Ocampo, L. M., Fulbright, D. W., and Hausbeck, M. K. 2009. Susceptibility of Fraser fir to Phytophthora capsici. Plant Dis. 93:135-141.

35. Quesada-Ocampo, L. M., and Hausbeck, M. K. 2010. Resistance in tomato and wild relatives to crown and root rot caused by Phytophthora capsici. Phytopathology 100:619-627.

36. Ristaino, J. B., and Johnston, S. A. 1999. Ecologically based approaches to management of Phytophthora blight on bell pepper. Plant Dis. 83:1080-1089.

37. Ristaino, J. B., Larkin, R. P., and Campbell, C. L. 1994. Spatial dynamics of disease symptom expression during Phytophthora epidemics in bell pepper. Phytopathology 84:1015-1024.

38. Saxton, A. M. 1998. A macro for converting mean separation output to letter groupings in Proc Mixed. Pages 1243-1245 in: 23rd SAS Users Group Int. SAS Institute, Nashville, TN.

39. Schlub, R. L., and Johnston, S. A. 1982. Control of Phytophthora on pepper using captafol and metalaxyl. Phillip. Agric. 65:215-219.

40. Shaner, G., and Finney, R. E. 1977. The effect of nitrogen fertilization on the expression of slow-mildewing resistance in Knox wheat. Phytopathology 67:1051-1056.

41. Simons, J. N., Simons, J. E., and Simons, J. L. 1990. Control of Phytophthora crown rot in bell pepper with directed sprays of metalaxyl. Proc Fla. State Hortic. Soc. 103:120-121.

42. Springer, J. K., and Johnston, S. A. 1982. Black polyethylene mulch and Phytophthora blight of pepper. Plant Dis. 66:281.

43. Waterhouse, G. M. 1963. Key to the species of Phytophthora de Bary. Mycol. Pap. 92:1-22.

44. Xie, J., Cardenas, E. S., Sammis, T. W., Wall, M. M., Lindsey, D. L., and Murray, L. W. 1999. Effects of irrigation method on chili pepper yield and Phytophthora root rot incidence. Agric. Water Manage. 42:127-142.

45. Yandoc-Ables, C. B., Rosskopf, E. N., and Lamb, E. M. 2007. Management of Phytophthora crown rot in pumpkin and zucchini seedlings with phosphonates. Plant Dis. 91:1651-1656. 